\title{
Effect of Packaging on Perceived Quality and Brand Loyalty: The Mediating Role of Brand Association in Over-the-Counter Market
}

\author{
John Mensah ${ }^{1}$, Peter Kwasi Oppong2, Matilda Addae ${ }^{1}$ \\ ${ }^{1}$ Department of Procurement and Supply Chain Management, Cape Coast Technical University, Cape Coast, Ghana \\ ${ }^{2}$ Department of Entrepreneurship and Business Sciences, University of Energy and Natural Resources, Sunyani, Ghana \\ Email: ‘jmjohnmensah@gmail.com, peteroppong72@gmail.com, addaematilda13@gmail.com
}

How to cite this paper: Mensah, J., Oppong, P. K., \& Addae, M. (2022). Effect of Packaging on Perceived Quality and Brand Loyalty: The Mediating Role of Brand Association in Over-the-Counter Market. Open Journal of Business and Management, 10, 297-313.

https://doi.org/10.4236/ojbm.2022.101018

Received: September 28, 2021

Accepted: January 15, 2022

Published: January 18, 2022

Copyright $\odot 2022$ by author(s) and Scientific Research Publishing Inc. This work is licensed under the Creative Commons Attribution International License (CC BY 4.0).

http://creativecommons.org/licenses/by/4.0/

\begin{abstract}
Distinctive packaging design and strong brand association are essential elements to increase brand quality and customer loyalty which can insulate a company against competitive actions in a retail environment. However, there is a relative scarcity of studies on the impact of packaging on brand quality and loyalty through the mediating effect of brand association in the overthe-counter health market. Against this background, the current study aimed to investigate the packaging's effect on brand quality and loyalty through the intervening effect of brand association in the over-the-counter health market. Using a systematic sampling technique, survey questionnaires were distributed to 348 customers shopping in the over-the-counter market. The data gathered were statistically analysed using structural equation modelling via SPSS Amos 20. The research revealed that brand association partially mediates the path between packaging and brand quality but fully mediates the packaging's effect on brand loyalty in the over-the-counter health market. The study also found that brand quality plays a partial role in the impact of brand association on loyalty in the over-the-counter health market. The study, therefore, established that the interplay of product packaging and brand association are crucial elements for enhancing the brand quality and the customers' loyalty in the over-the-counter health market. Besides, the research confirmed that enhanced association and quality are pre-requisite for developing and enriching loyalty in the over-the-counter health market.
\end{abstract}

\section{Keywords}

Packaging, Brand Association, Brand Quality, Brand Loyalty, Herbal Medicine 


\section{Introduction}

The use of over-the-counter (OTC) medicines has gained popularity over the world due to their immense contributions to health care delivery, particularly in remote communities where health care facilities are non-existent. The over-thecounter health care system offers several treatment options and quick access to medicines to fight minor sicknesses (DeLorme, Hu, Reid, \& Ann, 2010). Herbal medicines sold in Ghana at retail pharmacies, OTC medicine stores and herbal shops are often considered as non-prescription medications (WHO, 2011; WHO, 2005). Herbal medicines are "processed plant materials or raw plant materials and herbal medicinal products with therapeutic or human benefits derived from one or more plants" (WHO, 1998: p. 6). In the OTC health market, the medicinal products dispensed have less risk profile (Calamusa et al., 2012) and as a result, patients are allowed to buy them with little or no directions by a physician. Consequently, the medicinal product packaging is a key source of information that patients can refer to for safe and effectual use of the medicines (WHO, 2002). Berman (2004) pointed out that about one-third of medicinal errors are attributed to ineffective packaging design, whilst one-fourth are linked to poor drug naming, which creates potential treatment failures. Effective medicinal product packaging is, therefore, a mandatory requirement in the drug industry (Ghana Food \& Drugs Authority, 2013).

According to UNDP (2007), more than half of Ghanaians depend on herbal medicines to treat and manage their ailments. This might have led to the proliferation of herbal medicinal products in the OTC health market in the last few years. As result, there is keen competition in the OTC health market resulting in low-profit margins. It has been emphasized that distinctive packaging design does not only differentiate one brand from another (Keller, 2013) but also increases the perceived quality (Wang, 2013), brand association (Oppong \& Phiri, 2018) and customer loyalty (Dhurup, Mafini, \& Dumasi, 2014), which can ensure the herbal medicinal products' success in a competitive retail environment.

The potential role of packaging in strengthening perceived quality (e.g., Underwood \& Klein, 2002; Wang, 2013), brand association (e.g., Underwood, 2003; Oppong \& Phiri, 2018) and customer loyalty (e.g., Dhurup et al., 2014; Oppong \& Phiri, 2018) has been extensively studied of late. Again, a recent research conducted by Oppong, Yeboah and Gyawu (2020), examined the intervening role of brand association in the impact of brand awareness and perceived quality on loyalty. However, there is little or no research on the impact of packaging on perceived quality and loyalty through the brand association's mediational effect. Against this background, the current research aimed to investigate the packaging's effect on perceived quality and brand loyalty through the brand association's mediational role in the OTC health market in Ghana.

This research, therefore, advances the existing brand literature by bringing to fore the importance of brand association's mediational role in the packaging's effect on brand quality and loyalty, particularly in the OTC market. The study 
also adds to the prior brand theory by highlighting the brand quality's mediational effect in the path between brand association and loyalty in the OTC health market. Again, the study serves as a point of reference to motivate herbal practitioners to exploit packaging and brand association to increase the brand quality and customers' loyalty in the OTC market. Besides, the research extends the herbal practitioners' knowledge in building brand association and herbal medicinal brands' quality to enhance customers' loyalty in the OTC market. Enhanced perceived quality and a large customer loyalty base can sustain herbal medicine firms in the stiff competitive OTC market in Ghana.

The rest of the paper provides the literature review, conceptual framework and hypotheses, the research methodology, and the data analysis and results. The paper then ends with a discussion, implications of the findings, conclusion, limitation and direction for future research.

\section{Theoretical Review}

\subsection{Customer-Based Brand Equity}

A brand with powerful equity is recognized as one of the invaluable and strategic assets of a company because it creates a long-term cash flow. Brand equity is described as the extra value a product accrues due to the company's prior efforts in marketing the brand (Keller, 1993). Keller (2013) reported that positive brand equity conveys numerous advantages to a firm, such as increased perception of brand performance, promotion effectiveness, large margins, less vulnerability to marketing crisis and competitive actions, and more inelastic to price increases.

The concept of brand equity has been studied in three different ways, including financial-based, customer-based, and employer-based perspectives. According to Keller (1993: p. 1), customer-based brand equity (CBBE) measures "the differential effect that the brand knowledge has on consumer response to the marketing of that brand". A brand, therefore, has positive or negative CBBE when it commands more or less favourable reactions from the customers to a product and how it is marketed compared to the product's fictitious version. The underlying notion of the $\mathrm{CBBE}$ is that the power of a brand lies in the strength of the brand knowledge in the customers' memory, resulting from previous experiences with the brand. The source of $\mathrm{CBBE}$ is, therefore, the customers' brand knowledge, consisting of brand awareness and brand image. Thus, CBBE is created when customers have strong brand awareness and hold some strong, favourable and unique brand associations in memory.

Alternatively, Aaker (1991) explained that brand equity consists of assets and liabilities linked to a brand name or symbol that increase or reduce the product's value to a company and its clients. These brand assets include brand name awareness, brand loyalty, brand association, perceived quality and other proprietary brand assets like patents, trademarks, etc. The author established that brand loyalty, brand awareness, brand association and perceived quality are the key sources of CBBE. A review of the literature shows that Aaker's CBBE model 
has been extensively used in many different contexts, and hence, this paper adopted this model.

\subsection{Brand Loyalty}

Brand loyalty measures customers' positive attitude toward a particular brand (Pride \& Ferrell, 2015). Oliver (2015: p. 432) also defined loyalty as "a deeply held commitment to rebuy or re-patronise a preferred product or service consistently in the future, despite situational influences and marketing efforts having the potential to cause switching behaviour". Chaudhuri and Holbrook (2001) suggested that brand loyalty consists of attitudes and behaviours. Behavioural loyalty indicates consumers' re-patronage of a brand, whereas attitudinal loyalty describes a customer's commitment to a brand. Oliver (2015), however, distinguished four types of loyalty based on their increasing scope; cognitive, affective, conative and action loyalty. Cognitive loyalty is directed towards the brand's performance features, affective loyalty focuses on the brand's likeableness, conative loyalty expresses the consumer's socially committed intention to repurchase the brand, and action loyalty denotes a commitment to the action of rebuying. A large customer loyalty base creates an opportunity to gain large market share, word-of-mouth referrals, a barrier to competitors' entry and action, and higher profitability (Chaudhuri \& Holbrook, 2001; Aaker, 1996).

\subsection{Conceptual Framework}

The conceptual model delineates the main variables used and their proposed relationships in the research (Miles \& Huberman, 1994). In the current research, packaging is a predictor variable, the brand association is an intervening variable, whilst perceived quality and brand loyalty are outcome variables. Again, brand association is an independent variable, perceived quality is an intervening variable and loyalty is an outcome variable. The conceptual framework depicted in Figure 1 shows that packaging has a direct influence on the association, perceived quality and brand loyalty. Moreover, brand association positively affects perceived quality and loyalty, whilst perceived quality also has a direct effect on brand loyalty.

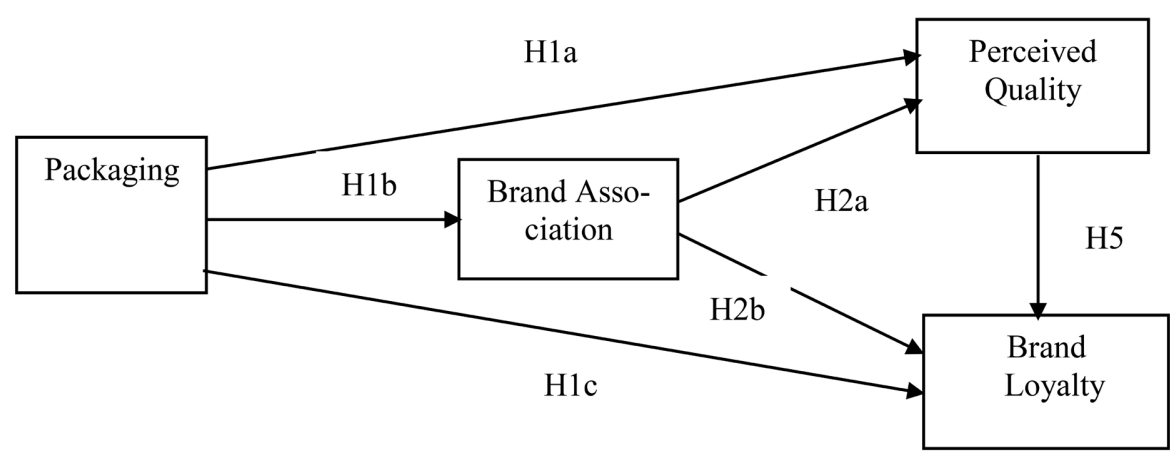

Figure 1. Conceptual model. 
In the present study, the packaging is described as producing a container and a graphic design for a product (Pride \& Ferrell, 2015). Likewise, the brand association also indicates anything that is connected to the brand by consumers which include perceived value, brand personality and organizational characteristics (Aaker, 1991). Perceived quality is operationalized as the judgement about the excellence or superiority of a product (Zeithaml, 1988), whilst brand loyalty is customers' favourable attitudes and behavioural disposition towards a particular brand.

\subsection{Research Hypotheses}

Guided by the study's conceptual framework and literature, the proposed hypotheses are explained below.

\subsubsection{Packaging}

Product packaging plays a vital role in consumer buying behaviour because it is buyers' first exposure to the product and creates lasting impressions during the time of purchase and consumption. Packaging is defined as designing and producing the container for a product (Kotler \& Keller, 2016). Similarly, Pride and Ferrell (2015: p. 282) also described "packaging as the development of a container and a graphic design for a product". Product packaging is usually made up of three layers namely, primary, secondary and tertiary packaging. The primary package is in direct contact with the product and the secondary package protects the product in the primary package and may be disposed of once the product is being used up. The tertiary package surrounds the earlier types of packages and facilitates the distribution, unification and protects the product in the entire supply chain (Simms \& Trott, 2010; Ampuero \& Vila, 2006). Zeithaml (1988) noted that packaging is both an intrinsic and extrinsic feature of a product. The intrinsic attribute is an integral part of the ingredients of the product, whilst the extrinsic relates to the product information attached to the package. Underwood (2003) also positioned packaging as an intrinsic attribute, an element of the product that is often essential in building and transmitting the brand's identity to consumers. Keller (1993), however, contended that a product package is one of the attributes of a brand and is not part of the core ingredients for a product to function, but rather facilitates the purchase and consumption process.

Kotler and Armstrong (2012) emphasized that the basic function of packaging in the past was to hold and protect the product in the distribution chain. However, increased competition in the retail and self-service environment have changed the role of packaging to perform an important marketing tool by seizing consumers' attention, describing the product's features and creating consumer confidence and making sales (Kotler \& Armstrong, 2012; Kotler \& Keller, 2016). Simms and Trott (2010) asserted that well-designed packaging influences consumers' buying decisions at the point of sale and can reinforce the product's success, particularly in the fast-moving consumer goods industry. 
Underwood (2003) also noted that the visual and structural qualities of packaging such as colours, fonts, brand logo, packaging materials, shapes, product information and other elements communicate the brand's personality, creating a unique brand association. Moreover, visual, verbal and tactile attributes of packaging provide a cue of product performance, quality, usage situations, and evoke past experiences in the consumer's memory (Garber, Burke, \& Morgan, 2000). WHO (2002) also pointed out that the quality of medicinal products is largely inferred from their packaging. Consequently, a product's packaging is a key determinant of its quality (Silayoi \& Speece, 2007). Hess et al. (2014) highlighted that packaging can enhance consumer satisfaction which underlies greater loyalty and profitability. Prior studies also indicate that packaging positively influences perceived product quality (Underwood \& Klein, 2002; Wang, 2013), brand association (Underwood, 2003; Oppong \& Phiri, 2018) and brand loyalty (Dhurup et al., 2014; Oppong \& Phiri, 2018). Hence, the following propositions are posited:

H1a: There will be a significant and direct relationship between packaging and perceived quality.

H1b: There will be a significant and direct relationship between packaging and brand association.

H1c: There will be a significant and direct relationship between packaging and brand loyalty.

\subsubsection{Brand Association}

Brand associations relate to anything that the consumer mentally attached to the brand (Aaker, 1991). Aaker (1996) is of the view that brand association includes perceived value, brand personality and organizational associations. Zeithaml (1988) explained perceived value as the subjective evaluation of the utility of the product based on what is received and given out. Brand personality refers to a set of human traits linked to the brand, and it tends to reflect the emotions and feelings evoked by the brand (Keller, 1993). Finally, the organizational association relates to the organisational aspects (people, values, and programs) that are associated with the brand.

Aaker (1991) stated that brand associations can position, distinguish and extend the brand name to other brands. Furthermore, consumers depend on brand associations to retrieve, organise and process the product information in their minds before deciding to buy a product. Past studies show that brand association has a direct impact on loyalty (Oppong, Yeboah, \& Gyawu, 2020; Azadi, Esfahani, \& Mohammadpoori, 2015) and perceived quality (Listiana, 2015; Falahat, Chuan, \& Kai, 2018). In turn, the brand association is positively influenced by packaging (Underwood \& Klein, 2002; Oppong \& Phiri, 2018). Consequently, the following propositions are posited:

H2a: There will be a significant and direct relationship between brand association and perceived quality. 
H2b: There will be a significant and direct relationship between brand association and brand loyalty.

H3: Brand association mediates the relationship between packaging and perceived quality.

$\mathrm{H} 4$ : Brand association mediates the relationship between packaging and brand loyalty.

\subsubsection{Perceived Quality}

Zeithaml (1988) defined perceived quality as the consumer's subjective assessment of excellence or superiority of a product. Aaker (1991) highlighted that perceived quality differs from actual product quality where the latter relates to the extent to which a product or service provides superior service. Zeithaml (1988) further distinguished between product-based quality and manufacturing-based quality. In the author's view, product-based quality indicates the nature and quantity of ingredients that make up a product, whereas manufacturing-based quality relates to conformance to production or service requirements. Aaker (1991) suggested that customers consider the quality of a product based on its performance, features, reliability, conformance, durability, serviceability, fit and finish. It has been emphasised that high perceptions of brand quality can drive consumers to select the brand rather than its competing brands (Yoo, Donthu, \& Lee, 2000). Aaker (1992) highlighted that high perceived quality can be a basis of differentiation, purchase decision, line extensions, and willingness to pay a price premium and overall, contributing to a firm's profit margin. Empirical studies also revealed that high perceived brand quality has a significant and positive relationship with loyalty (Alhaddad, 2015; Oppong et al., 2020), and is positively affected by brand associations (Listiana, 2015; Falahat et al., 2018). As a result, the following propositions are posited:

H5: There will be a significant and direct relationship between perceived quality and brand loyalty.

H6: Perceived quality mediates the relationship between brand association and brand loyalty.

\section{Research Methodology}

The methodology employed to evaluate the proposed hypotheses is explained below.

\subsection{Research Population and Sampling}

The targeted product for the study was locally-made herbal medicines sold as non-prescription medicines. These herbal medicines have been licensed and certified by the Ghana Food and Drugs Authority, the body which regulates the production and sale of herbal medicines in the country. Moreover, licensed herbal shops were included in the study rather than the retail pharmacies and OTC medicine stores because the herbal shops have been mandated to sell only herbal 
medicinal products, making it easy to recruit the research participants. The research had a population of 3710 customers who make daily purchases of herbal medicinal products from 80 licensed herbal shops in the Central Business District in Kumasi. The number of herbal shops operating in the Central Business District was obtained from the 2020 data of the Kumasi Traditional Medicine Practice Council which has been given the power to register the herbal shops in the metropolis. A sample of 348 customers was obtained by using Krejcie and Morgan's (1970) model of sample size formula.

$s=X^{2} N P(1-P) \div d^{2}(N-1)+X^{2} P(1-P)$.

$s=$ required sample size.

$X^{2}=$ the table value of chi-square for 1 degree of freedom at the desired confidence level (3.841).

$N=$ the population size.

$P=$ the population proportion (assumed to be .50 since this would provide the maximum sample size).

$d^{2}=$ the degree of accuracy expressed as a proportion (.05).

Given the study's population $=3710$.

$s=3.841 \times 3710 \times .50(1-.50) \div .05^{2}(3710-1)+3.841 \times .50(1-.50)$.

$s=3562.5275 \div 10.23275$.

Sample size $=348$.

\subsection{Scale Items Development and Administration}

Multiple scale items with five-point responses anchored on strongly disagreed (1) to strongly agree (5) were employed to measure the perceptions of customers' loyalty, association, quality and packaging of herbal medicinal products. The scale items were developed from previous studies. As a result, the scale items for measuring perceived quality were adapted from Gil, Andres and Martinez (2007) and Yoo et al. (2000), and those of brand associations were from Aaker (1996) and Tong and Hawley (2009). Likewise, the scale items for brand loyalty were obtained from Tong and Hawley (2009) and Yoo et al. (2000) and those of packaging were developed by the researchers.

The questionnaires were self-administered to the customers while shopping via a systematic sampling method. Thus, the first customer was randomly picked and afterwards, one of every eleventh customer was invited to participate in the survey. A systematic sampling strategy was employed as it made it possible to reach the respondents without prior information about them in the sample frame (Malhotra \& Birks, 2007). Although 316 questionnaires were distributed, 307 were used for the analysis because of poor responses.

\section{Data Analysis and Results}

The analytical tool employed to examine the research hypotheses was structural equation modelling (SEM) via SPSS Amos 20. 


\subsection{Sample Characteristics}

The sample characteristics show that a total of (208) 68.4 percent were male, whilst (96) 31.6 percent were female. More so, (124) 40.7 per cent were between the age of 18 and 25 years, (120) 39.2 per cent had completed Senior high school and (110) 36.7 per cent were traders. These results indicate that a large proportion of the samples were young, petty traders and hold secondary education.

\section{Descriptive Statistics}

The main purpose of the research was to evaluate the intervening role of brand association in the impact of packaging on perceived quality and brand loyalty in the OTC herbal market. Table 1 provides the descriptive statistics of how the customers assess the packaging, brand association, quality and loyalty based on their perceptions and experience. Overall, the customers' perceptions are satisfactory. The packaging has the highest mean value, followed by perceived quality and brand association and the least is brand loyalty.

Table 1. Summary results of study' variables descriptive statistics.

\begin{tabular}{cccccc}
\hline Variables & N & Minimum & Maximum & Mean & Standard Deviation \\
\hline Packaging & 307 & 1 & 5.00 & 3.758 & .762 \\
Perceived Quality & 307 & 1 & 5.00 & 3.691 & .886 \\
Brand Association & 307 & 1 & 5.00 & 3.691 & .785 \\
Brand Loyalty & 307 & 1 & 5.00 & 3.670 & .872 \\
\hline
\end{tabular}

\subsection{Structural Equation Modelling}

The SEM was adopted to evaluate the hypotheses formulated in the research due to its capability of examining the individual multiple equations simultaneously, providing the overall fit of the model and a window for the model's modification (Hair et al., 2010; Byrne, 2016). Following Anderson and Gerbing (1988) procedure for conducting SEM, the confirmatory factor analysis (CFA) was performed before the path analysis.

\subsection{Confirmatory Factor Analysis}

The CFA was conducted to determine whether the scale items load on their respective variables and to assess construct reliability and validity. Twenty (20) scale items were subjected to the CFA.

To enhance the convergent validity, standardised loadings below .50 were eliminated from the analysis (Hair et al., 2010), and hence, 11 scale items were retained. The results in Table 2 show that the standardised loadings of all the constructs were statistically significant at $p<.001$, and varied from .564 to .878 . Furthermore, the model fit indices were quite good except for the Chi-square statistic (CMIN $=110.135, \mathrm{DF}=38, p<.001$ ) due to its biasedness toward sample size. The Normed Chi-Square statistic $(\mathrm{CMIN} / \mathrm{DF})=2.898$; Goodness-of-Fit Index $(\mathrm{GFI})=.939$; Root Mean Residual $(\mathrm{RMR})=.051$; Standardised Root Mean Residual $(\mathrm{SRMR})=.045$; Root Mean Square Error of 
Table 2. Summary results of confirmatory factor analysis.

\begin{tabular}{|c|c|c|c|c|c|c|}
\hline & Construct and Scale Items & $\mathrm{N}$ & M & SD & $\begin{array}{l}\text { Standardised } \\
\text { Loadings }\end{array}$ & t-value \\
\hline \multicolumn{7}{|c|}{ Packaging } \\
\hline PA2 & $\begin{array}{l}\text { The packaging preserves } \\
\text { the contents of } \mathrm{X}\end{array}$ & 307 & 3.596 & .855 & .564 & - \\
\hline PA4 & $\begin{array}{l}\text { The packaging of X makes X } \\
\text { environmentally-friendly }\end{array}$ & 307 & 3.876 & 1.075 & .712 & 8.606 \\
\hline PA5 & $\begin{array}{l}\text { The packaging of } \mathrm{X} \text { makes } \mathrm{X} \\
\text { convenient to use }\end{array}$ & 307 & 3.997 & .992 & .848 & 8.760 \\
\hline \multicolumn{7}{|c|}{ Brand Loyalty } \\
\hline BL5 & $\begin{array}{l}\text { I will keep on buying } \mathrm{X} \text { as long as I } \\
\text { am satisfied with the packaging of } \mathrm{X}\end{array}$ & 307 & 3.896 & 1.101 & .790 & - \\
\hline BL4 & $\begin{array}{l}\text { The packaging of } X \\
\text { makes me loyal to } X\end{array}$ & 307 & 3.700 & 1.121 & .757 & 12.867 \\
\hline BL2 & $\begin{array}{l}\text { The packaging of } \mathrm{X} \text { would make me } \\
\text { recommend } \mathrm{X} \text { to my friends }\end{array}$ & 307 & 3.652 & 1.009 & .745 & 12.669 \\
\hline \multicolumn{7}{|c|}{ Perceived Quality } \\
\hline PQ1 & $\begin{array}{l}\text { The packaging of } \mathrm{X} \text { makes } \\
\mathrm{X} \text { function well }\end{array}$ & 307 & 3.336 & 1.127 & .878 & - \\
\hline PQ2 & $\begin{array}{c}\text { The packaging of } \mathrm{X} \text { makes } \\
\mathrm{X} \text { very reliable }\end{array}$ & 307 & 3.570 & 1.037 & .823 & 15.799 \\
\hline PQ4 & $\begin{array}{l}\text { I can always trust this X's } \\
\text { packaging for quality if I } \\
\text { want a brand of high quality }\end{array}$ & 307 & 3.893 & 1.134 & .599 & 10.859 \\
\hline \multicolumn{7}{|c|}{ Brand Association } \\
\hline BAS2 & $\begin{array}{l}\text { This X's packaging makes } \\
\text { me like the image of X }\end{array}$ & 307 & 3.678 & .948 & .711 & - \\
\hline BAS1 & $\begin{array}{l}\text { This X's packaging makes X } \\
\text { offer good value for money }\end{array}$ & 307 & 3.430 & 1.044 & .732 & 8.909 \\
\hline
\end{tabular}

Notes: $\mathrm{N}=$ No. of observations; $\mathrm{M}=$ Mean; $\mathrm{SD}=$ Standard deviation; $\mathrm{X}=$ Focal brand; a $=$ path parameter was set to 1 , therefore $\mathrm{t}$-values were not estimated; all regression weights are significant at $p=.001$.

Approximation $($ RMSEA $)=.079$; Comparative Fit Index $(\mathrm{CFI})=.947$; Tucker-Lewis Index $(\mathrm{TLI})=.924$; Incremental Fit Index $(\mathrm{IFI})=.948$; Normed Fit Index (NFI) $=.923$, show a good model fit (Hu \& Bentler, 1999; Kline, 2005; Hair et al., 2010).

\subsection{Psychometric Properties}

The psychometric properties investigated in this paper were internal consistency reliability and construct validity, which is determined by convergent and discriminant validity. Table 3 presents the outcomes of the psychometric properties which indicate that all the variables have satisfactory validity and internal consistency reliability.

The scale items' internal consistency reliability was all satisfactory, ranging 
Table 3. Summary results of psychometric properties.

\begin{tabular}{cccccccr}
\hline Latent Variables & $\alpha$ & CR & AVEs & PA & BL & PQ & BAS \\
\hline Packaging (PA) & .832 & .756 & .515 & $.718^{*}$ & & & \\
Brand Loyalty (BL) & .873 & .808 & .584 & .305 & $.764^{\star}$ & & \\
Perceived Quality (PQ) & .861 & .816 & .603 & .253 & .576 & $.777^{\star}$ & \\
Brand Association (BAS) & .811 & .685 & .521 & .240 & .477 & .426 & $.722^{*}$ \\
\hline
\end{tabular}

Notes: ${ }^{*}=$ Square root of AVEs; off-diagonal estimates measure the squared inter-construct correlations.

between .811 to .873 (Hair et al., 2010). Not only this but also, the findings of the composite reliability analysis show that all the values are within the required threshold of .70, supporting construct reliability (Fornell \& Larcker, 1981; Bagozzi \& Yi, 1988). The scores of Average Variance Extracted (AVEs) fall within the acceptable threshold of .50, supporting convergent validity (Fornell \& Lacker, 1981). Again, the square roots of the AVEs of the variables exceed the squared correlations between one variable and another, suggesting discriminant validity (Bagozzi \& Yi, 1988; Hair et al., 2010). These findings suggest that the variables are reliable and valid for the path analysis.

\subsection{Hypotheses Testing}

The hypotheses were examined through path analysis. As stated previously, the packaging is a predictor variable, the brand association is a mediating variable, whilst perceived quality and brand loyalty are outcome variables. Moreover, the brand association is considered an independent variable, perceived quality is a mediating variable and brand loyalty is a dependent variable.

Again, the Chi-square test $(\mathrm{CMIN}=110.135, \mathrm{DF}=38, p=.000)$ did not validate the path model. However, $\mathrm{CMIN} / \mathrm{DF}=2.898$; GFI $=.939$; RMR $=.051$; NFI $=.923 ; \mathrm{TLI}=.924 ; \mathrm{IFI}=.948 ; \mathrm{CFI}=.947 ; \mathrm{RMSEA}=.079$, supported the model.

The results of the path analysis in Table 4 show that packaging is significant and positively related to perceived quality, brand association and brand loyalty at a $p$ $<.05$ level, supporting H1a, H1b and H1c respectively. Furthermore, brand association has a significant and direct effect on perceived quality and brand loyalty at a $p<.05$, confirming $\mathrm{H} 2 \mathrm{a}$ and $\mathrm{H} 2 \mathrm{~b}$ respectively. Lastly, perceived quality has a sigTable 4. Summary findings of path analysis. nificant and positive effect on brand loyalty at $p<.05$ level, supporting H5.

\begin{tabular}{ccccccc}
\hline Hypotheses & \multicolumn{2}{c}{ Structural Relations } & Standardised Estimate & t-values & $p$-values \\
\hline H1a & Perceived Quality & $<--$ & Packaging & .240 & 3.102 & .002 \\
H1b & Brand Association & $<--$ & Packaging & .490 & 5.467 & .000 \\
H1c & Brand Loyalty & $<--$ & Packaging & .164 & .536 & .016 \\
H2a & Perceived Quality & $<---$ & Brand Association & .501 & .944 & .000 \\
H2b & Brand Loyalty & $<---$ & Brand Association & .295 & .141 & .002 \\
H5 & Brand Loyalty & $<---$ & Perceived Quality & .483 & 5.605 & .000 \\
\hline
\end{tabular}




\subsection{Mediation Testing}

The paper was also set out to examine the mediating role of the brand association in the impact of packaging on perceived quality $(H 3)$, and loyalty $(H 4)$. More so, the paper sought to identify the mediational role of perceived quality in the path between brand association and loyalty $(H 6)$.

Baron and Kenny's (1986) model for testing mediation was followed to analyse the mediational relationships posited in the current study. This involves; 1) regressing the mediating variable on the predictor variable; 2 ) the outcome variable on the predictor variable; and 3) the outcome variable on both the predictor variable and the mediating variable. Hence, the mediational relationships were tested using a bootstrap re-sampling technique of 2000 samples and a bias-corrected confidence level of $95 \%$ through SPSS Amos 20.

The findings of the data analysis in Table 5 show that the direct effect of packaging on perceived quality is significant at $p<.05$ level. Again, the findings reveal that the indirect effect of packaging on perceived quality is significant at $p$ $<.05$. These outcomes suggest that association partially mediates the relationship between packaging and perceived quality. Besides, the findings of the analysis indicate that the direct effect of packaging on brand loyalty is not statistically significant at $p<.05$. However, the indirect effect of packaging on loyalty is significant at $p<.05$ level. These outcomes demonstrate that association fully mediates that the relationship between packaging and loyalty.

Furthermore, the results of the analysis reveal that the direct effect of brand association on loyalty is significant at $p<.05$. The results also show that the indirect effect of brand association on loyalty is significant at $p<.05$. These outcomes show that perceived quality partially mediates the path between association and loyalty.

Table 5. Summary results of mediation model.

\begin{tabular}{ccccc}
\hline Hypotheses & Structural Relations & Direct without Mediator & Direct with Mediator & Indirect Effect \\
\hline H3 & Quality <-- Association <---Packaging & $240(.030)^{\star *}$ & $.490(.001)^{\star *}$ & $.262(.000)^{\star *}$ \\
H4 & Loyalty <-- Association <--- Packaging & $.164(.099)^{\star}$ & $.490(.001)^{\star *}$ & $.387(.001)^{\star *}$ \\
H6 & Loyalty <-- Quality <-- Association & $.295(.009)^{\star *}$ & $.536(.001)^{\star *}$ & $.259(.000)^{\star \star}$ \\
\hline
\end{tabular}

Notes: ${ }^{*}=$ Not statistically significant; ${ }^{* *}=$ Statistically significant.

\section{Discussions and Implications}

The paper was set out to investigate the mediating role of the brand association in the impact of packaging on perceived quality and loyalty in the OTC market in Ghana. The study found that innovative packaging design positively affects consumers' perceptions of medicinal herbal product quality in the OTC market. This outcome is consistent with previous studies (Underwood \& Klein, 2002; Wang, 2013), which suggested that well-designed packaging positively influences the perceived product quality in the market. Thus, herbal medicine customers 
judge the quality of the product on how well the packages have been designed in the OTC market. Consequently, the brand managers can increase customers' perceptions of quality by designing consumer-driven packages to provide convenience, preserves the content product and the ecology in the OTC market. More so, consistent with the prior studies (Underwood, 2003; Oppong \& Phiri, 2018), the study revealed that packaging contributes to strengthening the brand association in the OTC market. This implies that a well-designed product packaging potentially enhances medicinal herbal products' image because it provides the customers' value for money for their purchases. In this regard, an effort by the brand managers to design and harness innovative packaging will enrich the products' image in the market. Again, the study established that packaging significantly contributes to increasing customers' loyalty in the OTC health market. This outcome concurs with past studies (Dhurup et al., 2014; Oppong \& Phiri, 2018), which pointed out that packaging exerts a greater influence on loyalty. Greater satisfaction with a product packaging is a key indicator of customer loyalty, engendering word-of-mouth referral and repurchase intentions. Therefore, developing distinctive product packaging to delight the customers will strengthen their loyalty to herbal medicinal brands in the OTC health market.

Again, consistent with the findings of earlier authors (Listiana, 2015; Falahat et al., 2018), the study revealed that brand association has a direct impact on perceived herbal medicinal brand quality in the OTC market. This suggests that product brands with a favourable image are perceived to be reliable and of high performance. Hence, developing a brand with a positive image will increase its perceived quality, which may be a basis for differentiating the brand from its competitors in a highly competitive OTC health market. Furthermore, brand association was found to have a positive influence on loyalty in the market. This outcome concurs with earlier studies (Oppong et al., 2020; Azadi et al., 2015), which established that favourable brand association positively affects customer loyalty in the market. This implies that a product brand with a distinctive image reinforces customers' loyalty, manifesting in favourable word-mouth recommendation and re-patronage of the brands. Realising the immense role of loyalty in a cluttered retail environment, brand managers need to build a strong image of their brands to strengthen customers' loyalty in the market. The study's results also show that perceived quality has a significant and direct effect on loyalty in the OTC health market. This result is similar to the previous studies (Alhaddad, 2015; Oppong et al., 2020), which suggest that perceived quality exerts a strong impact on loyalty. Thus, customers develop loyalty for brands perceived to be more reliable and of greater performance than their counterparts in the market. Consequently, brand managers can increase the customer loyalty base by enhancing the perceived herbal medicinal product quality in the industry.

Again, the results of the analysis demonstrate that brand association fully mediates the impact of packaging and loyalty, but partially on perceived medicinal herbal product quality in the OTC market. This indicates that brand association 
fully contributed to the impact of packaging on loyalty, but partly on the perceived herbal product quality. This demonstrates that brand association plays a critical role in designing packaging to strengthen customers' loyalty and perceived herbal medicinal product quality in the OTC market. Thus, brand managers need to consider brand association in their strategic packaging decisions with the view to building favourable perceived quality and greater loyalty in the OTC health market. Finally, the results of the data analysis show that perceived quality perfectly mediates the impact of brand association and loyalty in the OTC health industry. This implies that perceived quality plays an essential role in developing brand association to create a large loyal customer base in the OTC market. Hence, brand managers should enhance perceived quality to fully benefit from exploiting brand association to reinforce customers' loyalty in the OTC industry.

\section{Conclusion}

The purpose of this paper was to identify the mediational role of the brand association in the impact of packaging on perceived quality and loyalty in the OTC health industry. The paper also sought to ascertain the intervening role of perceived quality in the relationship between brand association and loyalty. The research found that packaging exerts a greater influence on perceived quality, brand association and loyalty, and in turn, brand association positively influences the perceived quality and loyalty. More so, the study's results show that brand association perfectly mediates the impact of packaging on loyalty, and partially, on perceived product quality in the OTC health market. Finally, the results indicate that perceived quality partially mediates the path between brand association and loyalty in the OTC health market. The research, therefore, confirmed that the interplay of packaging and brand association is essential to establish high perceived quality and a large customer loyalty base in the OTC health industry. Not only this but also, the interaction between brand association and perceived quality is critical to reinforcing customers' loyalty in the OTC health industry.

\section{Limitations and Direction for Future Research}

There are some limitations of this paper that need to be redressed in a similar future to enrich the generalisation of its findings. Herbal medicines retailed in the in-store market were selected. Future research should consider those that are sold online to generate a holistic view of the brand's credibility, image, trust, value and customers' repurchase intentions of herbal medicines in the OTC herbal market in Ghana. Moreover, herbal medicines encompass herbal herbs, herbal materials, herbal preparations and finished herbal products. The current paper considered only the finished packaged herbal products sold at the OTC herbal market. Future studies should investigate all aspects of herbal medicines sold at the OTC market. Furthermore, the current research examined customers' per- 
ceptions of packaging, brand association, quality and loyalty in Ghana. Future research should consider collecting data from other parts of the country to enhance the generalisation of this study.

\section{Conflicts of Interest}

The authors declare no conflicts of interest regarding the publication of this paper.

\section{References}

Aaker, D. A. (1991). Managing Brand Equity: Capitalizing on the Value of Brand Name. The Free Press.

Aaker, D. A. (1992). The Value of Brand Equity. Journal of Business Strategy, 13, 27-32. https://doi.org/10.1108/eb039503

Aaker, D. A. (1996). Measuring Brand Equity across Products and Markets. California Management Review, 38, 102-120.

Alhaddad, A. (2015). Perceived Quality, Brand Image and Brand Trust as Determinants of Brand Loyalty. Journal of Research in Business \& Management, 3, 1-8.

Ampuero, O., \& Vila, N. (2006). Consumer Perceptions of Product Packaging. Journal of Consumer Marketing, 23, 100-112. https://doi.org/10.1108/07363760610655032

Anderson, J. C., \& Gerbing, D. W. (1988). Structural Equation Modelling in Practice: A Review and Recommended Two-Step Approach. Psychological Bulletin, 103, 411-423. https://doi.org/10.1037/0033-2909.103.3.411

Azadi, A., Esfahan, D. N., \& Mohammadpoori, H. (2015). Relationship between Brand Association and Brand Loyalty in the Fan of Private Clubs in Iran. Biomedical \& Pharmacology Journal, 8, 1025-1031. https://doi.org/10.13005/bpj/855

Bagozzi, R. P., \& Yi, Y. (1988). On the Evaluating Structural Equation Models. Journal of Academy of Marketing Research, 16, 74-94. https://doi.org/10.1007/BF02723327

Baron, R. M., \& Kenny, D. A. (1986). The Moderator-Mediator Variable Distinction in Social Psychology Research: Conceptual, Strategic, and Statistical Considerations. Journal of Personality and Social Psychology, 51, 1173-1182.

https://doi.org/10.1037/0022-3514.51.6.1173

Berman, A. (2004). Reducing Medication Errors through Naming, Labelling and Packaging. Journal of Medical Systems, 28, 9-29.

https://doi.org/10.1023/B:JOMS.0000021518.60670.10

Byrne, B. M. (2016). Structural Equation Modelling with AMOS: Basic Concepts, Applications and Programming (3rd ed.). Francis \& Taylor. https://doi.org/10.4324/9781315757421

Calamusa, A., Marzio, A. D., Cristofani, R., Arrighetti, P., Santaniello, V., Alfani, S., \& Carducci, A. (2012). Factors that Influence Italian Customers' Understanding of Overthe-Counter Medicines and Risk Perception. Patient Education and Counselling, 87, 395-401. https://doi.org/10.1016/j.pec.2011.10.003

Chaudhuri, A., \& Holbrook, M. B. (2001). The Chain of Effects from Brand Trust and Brand Affect to Brand Performance: The Role of Brand Loyalty. Journal of Marketing, 65, 81-93. https://doi.org/10.1509/jmkg.65.2.81.18255

DeLorme, D. E., Hu, J., Reid, L. N., \& Ann, S. (2010). The State of Public Research on Over-the-Counter Drug Advertising. International Journal of Pharmaceutical \& Health Care Marketing, 4, 208-231. https://doi.org/10.1108/17506121011076156 
Dhurup, M., Mafini, C., \& Dumasi, T. (2014). The Impact of Packaging, Price and Brand Awareness on Brand Loyalty: Evidence from the Paint Retailing Industry. Acta Commercii, 14, Article No. a194. https://doi.org/10.4102/ac.v14i1.194

Falahat, M., Chuan, C. S., \& Kai, S. B. (2018). Brand Loyalty and Determinants of Perceived Quality and Willingness to Order. Academy of Strategic Management Journal, 17, 1-10.

Fornell, C., \& Larcker, D. F. (1981). Evaluating Structural Equation Models with Unobservable Variables and Measurement Error. Journal of Marketing Research, 18, 39-50. https://doi.org/10.1177/002224378101800104

Garber, L. L. J., Burke, R. R., \& Morgan, J. J. (2000). The Role of Package Colour in Consumer Purchase Consideration and Choice. Working Paper Series, Report No. 00-104, Marketing Science Institute.

Ghana Food \& Drugs Authority (2013). Guidelines for Registration of Herbal Medicine Products in Ghana.

Gil, R. B., Andres, E. F., \& Martinez, E. S. (2007). Family as Source of Customer-Based Brand Equity. Journal of Product \& Brand Management, 16, 188-199.

https://doi.org/10.1108/10610420710751564

Hair, J. H. Jr., Black, W. C, Babin, B. J., \& Anderson, R. E. (2010). Multivariate Data Analysis (7th ed). Pearson Education.

Hess, J. S., Singh, J., Danes, J., \& Metcalf, L. E. (2014). Impact of Consumer Product Package Quality on Consumption Satisfaction, Brand Perceptions, Consumer Investment and Behaviour. Journal of Applied Packaging Research, 6, Article No. 4 https://doi.org/10.14448/japr.01.0003

Hu, L., \& Bentler, P. M. (1999). Cut-off Criteria for Fit Indexes in Covariance Structure Analysis: Conventional Criteria versus New Alternatives. Structural Equation Modelling: Multidisci plinary Journal, 6, 1-55. https://doi.org/10.1080/10705519909540118

Keller, K. L. (1993). Conceptualization, Measuring, and Managing Customer-Based Brand Equity. Journal of Marketing, 57, 1-22. https://doi.org/10.1177/002224299305700101

Keller, K. L. (2013). Strategic Brand Management: Building Measuring, and Managing Brand Equity (4th ed.). Pearson Education.

Kline, R. B. (2005). Principles and Practice of Structural Equation Modelling (2nd ed.). Guilford Press.

Kotler, P., \& Armstrong, G. (2012). Principles of Marketing (14th ed.). Pearson Education.

Kotler, P., \& Keller, K. L. (2016). Marketing Management (15th ed.). Pearson Education.

Krejcie, R. V., \& Morgan, D. W. (1970). Determining Sample Size for Research Activities. Educational and Psychological Measurement, 30, 607-610. https://doi.org/10.1177/001316447003000308

Listiana, E. (2015). Country-of-Origin Image and its Impact on Brand Association, Perceived Quality and Brand Loyalty. Journal of Marketing \& Consumer Research, 10, 1929.

Malhotra, N. K., \& Birks, D. F. (2007). Marketing Research: An Applied Approach (3rd ed.). Pearson Education Limited.

Miles, M. B., \& Huberman, A. M. (1994). Qualitative Data Analysis: An Expanded Sourcebook (2nd ed.). SAGE Publication, Inc.

Oliver, R. L. (2015). Satisfaction: A Behavioural Perspective on Consumer (2nd ed.). Routledge.

Oppong, P. K., \& Phiri, M. A. (2018). Impact of Brand Awareness and Association on 
Loyalty: The Role of Equity in the Plant Medicine Market in Kumasi, Ghana. African Journal of Business \& Economic Research, 13, 163-181. https://doi.org/10.31920/1750-4562/2018/v13n2a8

Oppong, P. K., Yeboah, S. T., \& Gyawu, A. (2020). Influence of Brand Awareness and Perceive Quality on Loyalty: The Mediating Role of Association in Traditional Medicine Market in Kumasi, Ghana. Information Management and Business Review, 12, 1-11. https://doi.org/10.22610/imbr.v12i2(I).3035

Pride, W. M., \& Ferrell, O. C. (2015). Foundations of Marketing (6th ed.). USA: Cengage Learning.

Silayoi, P., \& Speece, M. (2007). The Importance of Packaging Attributes: A Conjoint Analysis Approach. European Journal of Marketing, 41, 1494-1517.

https://doi.org/10.1108/03090560710821279

Simms, C., \& Trott, P. (2010). Packaging Development: A Conceptual Framework for Identifying New Product Opportunities. Marketing Theory, 10, 397-415. https://doi.org/10.1177/1470593110382826

Tong, X., \& Hawley, J. M. (2009). Measuring Customer-Based Brand Equity: Empirical Evidence from Sportswear Market in China. Journal of Product \& Brand Management, 18, 262-271. https://doi.org/10.1108/10610420910972783

Underwood, R. L. (2003). The Communicative Power of Product Package: Creating Brand Identity via Lived and Mediated Experience. Journal of Marketing Theory \& Practice, 11, 62-76. https://doi.org/10.1080/10696679.2003.11501933

Underwood, R. L., \& Klein, N. M. (2002). Packaging as a Brand Communication: Effects of Product Pictures Consumer Responses to Packaging and Brand. Journal of Marketing Theory \& Practice, 10, 58-68. https://doi.org/10.1080/10696679.2002.11501926

UNDP (United Nations Development Programme) (2007). The Ghana Human Development Report: Towards a More Inclusive Society. United Nations Development Programme.

Wang, E. S. T. (2013). The Influence of Visual Packaging Design on Perceived Food Product Quality, Value, and Brand Preference. International Journal of Retail \& Distribution Management, 41, 805-816. https://doi.org/10.1108/IJRDM-12-2012-0113

WHO (World Health Organization) (1998). Guidelines for Appropriate Use of Herbal Medicines. WHO Regional Publication, Western Pacific Series, No. 23. World Health Organization.

WHO (World Health Organization) (2002). Guidelines on Packaging Pharmaceutical Products. Technical Report Series, World Health Organization.

WHO (World Health Organization) (2005). National Policy on Traditional Medicine and Regulation of Herbal Medicine. Report of a WHO Global Strategy, World Health Organization.

WHO (World Health Organization) (2011). Traditional Medicines, Global Situation, Issues and Challenges. The World Medicines Situation (3rd ed.). World Health Organization.

Yoo, B., Donthu, N., \& Lee, S. (2000). An Examination of Selected Marketing Mix Elements and Brand Equity. Journal of the Academy of Marketing Science, 28, Article No. 195. https://doi.org/10.1177/0092070300282002

Zeithaml, V. A. (1988). Consumer Perceptions of Price, Quality, and Value: A Means-End Model and Synthesis of Evidence. Journal of Marketing, 52, 2-22.

https://doi.org/10.1177/002224298805200302 